\title{
PERFORMANCE OF PRESTRESSED HOLLOWCORE SLABS WITH AND WITHOUT CUTOUTS
}

\author{
P Sameer Kumar Sarma ${ }^{1}$, S. Suriya Prakash ${ }^{2}$ \\ ${ }^{1}$ Research Scholar, Department of Civil Engineering, Indian Institute of Technology Hyderabad, India. \\ ce13p1007@iith.ac.in \\ ${ }^{2}$ Assistant Professor and Corresponding Author, Department of Civil Engineering, Indian Institute of Technology \\ Hyderabad, India.suriyap@iith.ac.in
}

\begin{abstract}
PrestressedHollowcore slabs are typicallyprecast using an extruder machine withprestressing strands as the only internal reinforcement. Various building servicesrequire cut-outs to be provided in these precast slabs.Cut-outs/openings in hollowcore slabs can coincide with the location of strands and may lead to their curtailment.An experimental study was carried out to evaluate the effect of cut-outs in hollowcore slabs. Four full scale tests were conducted by consideringtwo shear span to depth ratiosand out of which two slabs had flexural opening. The strength of concrete, prestressing ratio and size of opening was kept constant in all slabs. It was observed that, provision of cut-outs not only reduced the cracking and ultimate strength of slabs, but also altered the failure modeswith change in deformation capacity.
\end{abstract}

Keywords Cut-outs/openings, Prestress Precast, Hollowcore slabs, shear span to depth ratio

\section{INTRODUCTION}

Prestressedhollowcore elements are typically used as slab elements in buildings. Cut-outs in slabs/walls is one of the most common problems encountered during construction.Slabs may require provision of cut-outs for various structural purposes or for facilitating other building services. The size of these cut-outs can range from very small to large resulting inan adverse effect on the structural behaviour of the slab.The flexural strength and shear capacity of hollowcore slabs were studied by many researchers. Walraven and Mercx (1983), Becker and Buettner(1985), Pajari (1998), Hawkins and Ghosh (2006), Palmer and Schultz (2011) have studied the effect of various parameters like shear span to depth ratio, prestressing force, depth of slab, shape of voids on the strength of hollowcore slabs. Yang (1994) evaluated the effect of web interaction on behaviour of hollowcore slabs with a series of experimental studies.

\section{EFFECT OF CUT-OUTS}

\subsection{Reinforced Concrete Slabs}

The effect of cut-outson the behaviour ofreinforced concrete (RC) slab elements has been studied by various researchers in the past and some of the findings are reported in this section. Afefy and Fawzy(2013)carried outan experimental investigation on one way RC slabs with cut-outsand found thatthe ultimate strengthand deflection reduced by $50 \%$ and $45 \%$ respectively due to the provision of cut-outs. They noted that the decrease in ultimate strength was not directly proportional to the reduction in width of section due to opening. Al-hafiz et al. (2013) carried out experimental studies on one way RC slabs with thickness ranging from $40 \mathrm{~mm}$ to $80 \mathrm{~mm}$ with a cut-out width of $19 \%$ of width of the slab. They found that the ultimate strength decreased from $34 \%$ to $38 \%$. Further, it wasobserved that the thickness of slabs playeda major role in the reduction of ultimate strengthdue to cut-outs. Anil et al. (2013)studied the effect of width of opening located at both flexure and shear zones.Due to highershear span (a) to depth (d) ratio $(\mathrm{a} / \mathrm{d}$ =7)used in the study, the effect of opening was more dominant when the opening location was in flexure zone. They reported that the cut-outs in flexure zone reduced the ultimate strengths from $24 \%$ to $44 \%$.In general, it is observed that the strength and stiffness reduction was proportional to reduction in width of slab due to opening. They also noted that there was a change in failure mode depending on the location of the cut-outs.

\section{PRESTRESSED PRECAST HOLLOW CORE} SLABS

Johnson and Ghadiali (1972) carried out experiments on assembly of hollowcore slab units and evaluated the load distribution between slabs with discontinuity or opening. The authors cautioned that the cut-outs can have significant effect on the serviceability performance of hollowcore slabs. Foubert (2014) evaluated the effect of cut-outs in hollowcore slabs under flexure. The opening was located in either flexure or shear dominated zone. The author observed that opening in shear zone resulted in only $4 \%$ reduction in flexural capacity. However, the strength reduction increased to $17 \%$ when the opening was present in flexural zone.

\section{RESEARCH SIGNIFICANCE}

In general, prestressing strands are the only reinforcement in the hollow core slabs due to the limitation of its manufacturing process of casting by extrusion and because 
of its cross sectional shape.Cut-outs in hollowcore slabs could coincide with the location of strand and this maylead to its curtailment. Reduction in the area of prestressing reinforcement can significantly impact the strength and stiffness of hollow core slabs.It is important to understand the effect of cut-outs on failure progression, mode of failure and ultimate strength and stiffnessfor the safe design of hollowcore slabs. The present investigation experimentally evaluates the effect of opening in flexural zone at low and high $\mathrm{a} / \mathrm{d}$ ratios to simulate different levels of bending moment to shear force on the behaviour of hollowcore slabs.

\section{EXPERIMENTAL INVESTIGATION OVERVIEW}

Four full scale hollowcore slabs were tested to evaluate the effect of cut-outs on theirbehaviour and failure modes. All the slabs were $3.5 \mathrm{~m}$ long and had the same geometry as shown in the Figure 1. The slabs were prestressed with 6 numbers of strands of $9.53 \mathrm{~mm}$ diameter with a prestressingjacking force of $70 \mathrm{kN}$ each. All the slabs were cast on the same day and were cured at the same temperature. Two shear span to depth ratios $(\mathrm{a} / \mathrm{d})$ were selected.Two slabs were tested as control specimens witha/d ratios of 3.5 and 7.5. Other slabs had one opening of size 300 $\mathrm{mm} \times 600 \mathrm{~mm}(25 \%$ of the width of the slab) which was provided during casting atmid span location (Flexural Opening-FO). Cut-outs coincide with the axis of symmetry along the width of slabs. The plan view ofthe slabs with locations of opening is shown in Figure 2. Two prestressing strands located at the middle of the cross section were cut because of the opening. The test matrix shown in Table 1 summarizes the specimens and study parameters of the test program and Table 2 shows the cross sectional properties.

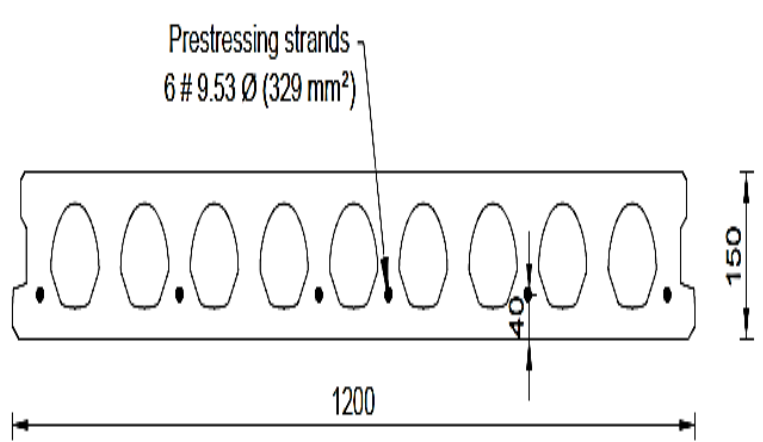

Figure 1: Cross section details of hollowcore slabs (Dimensions in $\mathrm{mm}$ )

Table 1: Test matrix

\begin{tabular}{|l|l|l|l|}
\hline $\begin{array}{l}\text { Specimen } \\
\text { Number }\end{array}$ & Label & $\begin{array}{l}\text { Shear } \\
\text { Span } \\
\text { to } \\
\text { Depth } \\
\text { (a/d) } \\
\text { ratio }\end{array}$ & \\
\hline 1 & HCS-150-3.50-NO & 3.50 & No Opening \\
\hline 2 & HCS-150-3.50-FO & 3.50 & Flexural Opening \\
\hline
\end{tabular}

\begin{tabular}{|l|l|l|l|}
\hline 3 & HCS-150-7.50-NO & 7.50 & No Opening \\
\hline 4 & HCS-150-7.50-FO & 7.50 & Flexural Opening \\
\hline
\end{tabular}

Table 2: Cross sectional details

\begin{tabular}{|c|c|c|c|c|c|c|c|}
\hline \multicolumn{4}{|c|}{ Full cross section } & \multicolumn{4}{|c|}{ Cross section at opening } \\
\hline $\begin{array}{l}\text { Are } \\
\mathbf{a} \\
(\mathbf{m} \\
\left.\mathbf{m}^{2}\right)\end{array}$ & $\begin{array}{l}\text { Mom } \\
\text { ent of } \\
\text { Inerti } \\
\text { a } \\
\left(\mathbf{m m}^{4}\right. \\
\text { ) } \times 10^{9}\end{array}$ & $\begin{array}{l}\text { CG } \\
\text { of } \\
\text { sect } \\
\text { ion } \\
(\mathbf{m} \\
\text { m) }\end{array}$ & $\begin{array}{l}\text { Prestr } \\
\text { essing } \\
\text { ratio } \\
\left(\mathbf{A}_{\mathrm{p}} / \mathbf{A}_{\mathrm{c}}\right. \\
)^{2}\end{array}$ & $\begin{array}{l}\text { Are } \\
\mathbf{a} \\
(\mathbf{m} \\
\left.\mathbf{m}^{2}\right)\end{array}$ & $\begin{array}{l}\text { Mo } \\
\text { men } \\
\text { t of } \\
\text { Iner } \\
\text { tia } \\
(\mathbf{m m} \\
\left.{ }^{4}\right) \\
\times 10^{9}\end{array}$ & $\begin{array}{l}\text { CG } \\
\text { of } \\
\text { sect } \\
\text { ion } \\
(m \\
\text { m) }\end{array}$ & $\begin{array}{l}\text { Prestr } \\
\text { essing } \\
\text { ratio } \\
\left(\mathbf{A}_{\mathrm{p}} / \mathbf{A}_{\mathrm{c}}\right. \\
)^{2}\end{array}$ \\
\hline $\begin{array}{l}120 \\
370\end{array}$ & 0.299 & $\begin{array}{l}75 . \\
3\end{array}$ & 0.273 & $\begin{array}{l}923 \\
64\end{array}$ & $\begin{array}{l}0.24 \\
4\end{array}$ & $\begin{array}{l}75 . \\
3\end{array}$ & 0.237 \\
\hline
\end{tabular}

\subsection{Material Properties}

\section{Concrete:}

All specimens were cast using normal weight, ready-mix concrete with a target compressive strength of $40 \mathrm{MPa}$ at 28 days. Zero slump concrete mix with10 $\mathrm{mm}$ nominal coarse aggregates were used. Casting of hollow core slabs was done with the help of extrusion machine. The unit weight of concrete was about $2400 \mathrm{~kg} / \mathrm{m}^{3}$. The tested concrete cube strength was $42 \mathrm{MPa}$ at 28 days.

Internal reinforcement - prestressing strands:

Seven-wire low-relaxation strands with an ultimate tensile strength of $1860 \mathrm{MPa}$ and modulus of elasticity of $196 \mathrm{GPa}$ were used. Strands of $9.53 \mathrm{~mm}$ diameter were used at the tension side of the slab with a jacking force of $70 \mathrm{kN}$ each.

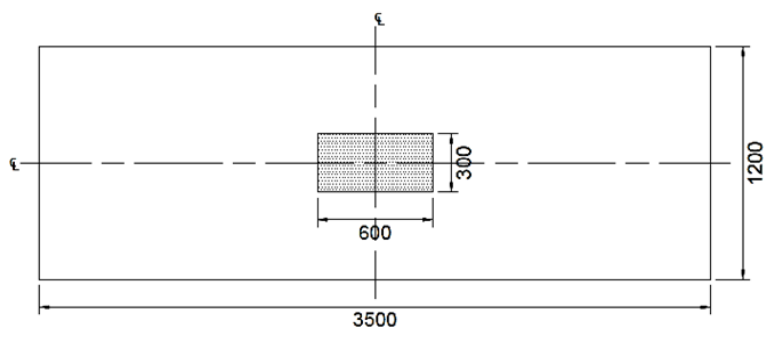

Figure 2: Location of Opening (Dimensions in $\mathrm{mm}$ )

\subsection{Test Setup and Loading Details}

The slabs were tested in a four-point bending configuration by which constant moment region at the mid-span was obtained. Figure 3 illustrates the components used in the test setup. A $250 \mathrm{kN}$ MTS hydraulic actuator was used to apply the load. The actuator load was transferred to the specimens via a single longitudinal rigid steel spreader beam stiffened with web stiffeners. The load from spreader beam was transferred to the slab through two transverse I-beams as two distributed line loads along the full width of the slab (Figure 3). Schematic of the test setup with shear span dimension and locations of linear variable differential transducer (LVDT) for displacement measurement are shown in Figure4. High strength cement mortar was used 
between the two transverse spreader I-beams and the slab to eliminate the surface irregularities and to provide a smooth surface to avoid any possible stress concentrations. End supports includerigid I-beams stiffened with transverse stiffeners. Loading was applied monotonically in displacement control mode at a rate of $0.05 \mathrm{~mm} / \mathrm{sec}$. Loading was intermittently paused to observe and mark the crack propagation and failure progression of the tested specimen.

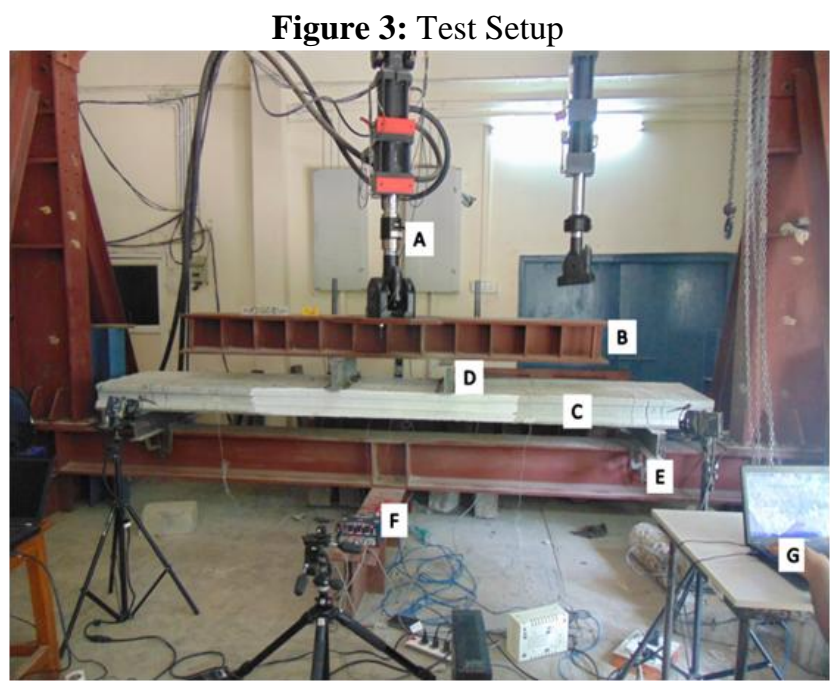

A. $250 \mathrm{KN}$ MTS Actuator B. Spreader Beam C. $3.5 \mathrm{~m}$ Hollowcore Slab D.Transverse I-beams E. Support I-beams F. HBM DAQ systemG.Laptop

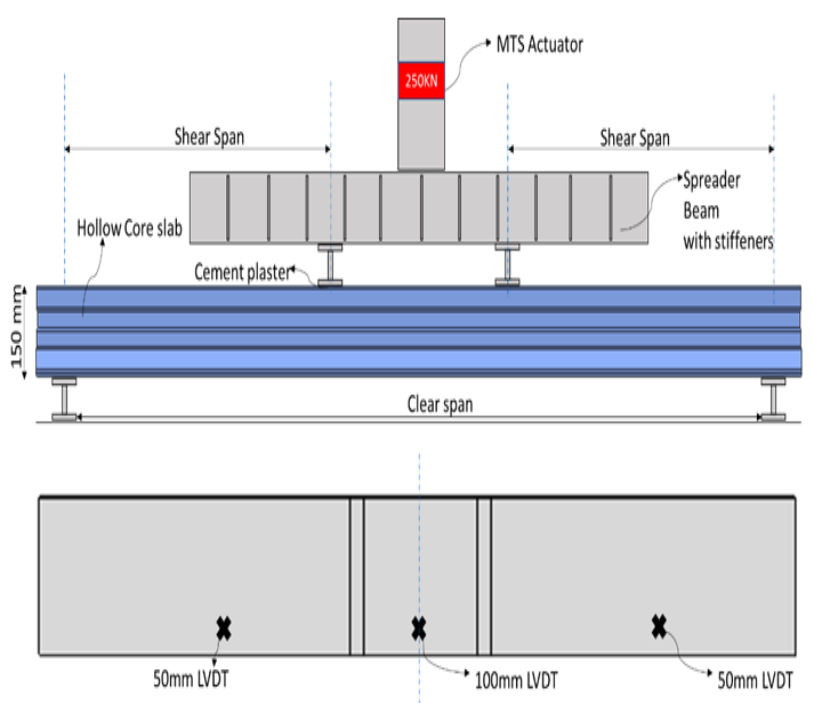

Figure 4: Schematic of Test Setup

\subsection{Instrumentation}

All specimens had similar instrumentation details. Deflections were recorded using LVDTs. Specific locations of LVDTs were chosen to capture the entire curvature profile during testing. Two $50 \mathrm{~mm}$ LVDTs were positioned at one third of clear span distance and one $100 \mathrm{~mm}$ LVDT was positioned at the centre of the span to capture mid-span deflection as shown in Figure 4.

\section{RESULTS AND DISCUSSION}

\subsection{Load Vs Deflection Behaviour}

The deflection response of the slabs was captured by the linear variable displacement transducer (LVDTs) and is plotted against theapplied load. Figures 6 shows the response of all the slabs. In series with a/d ratio of 3.5 , opening in both flexure zone had considerable effect on the cracking and ultimate strength of the slab. The control slab with a/d ratio of 3.5 had an ultimate strength of $181 \mathrm{kN}$ and failed in a brittle shear mode of failure. The initial crack occurred at $129 \mathrm{kNbetween}$ the loading point and support.Load drop was observed at $161 \mathrm{kNdue}$ to cracking in the other end of the constant shear zone. The slab had symmetrical cracking until the propagation of cracks turned into major diagonal shear cracks. The slab failed with the sudden drop in load under brittle shear failure mode.

The slab with a flexural opening (HCS-150-3.5-FO) in with $\mathrm{a} / \mathrm{d}$ ratio 3.5 had a change in failure mode because of the weaker section (due to opening) attracting more damage due to the presence of opening. Though the chosen $\mathrm{a} / \mathrm{d}$ ratio is a shear dominated one, the slab had initial flexural cracking in the constant moment zone at the corner of the opening. Crack distribution occurred in the opening location causing minor load drops which can be seen from the load deflection curve. Load steadily picked up on further loading due to the action of strandsleading to large ductility of the slab. The slab resisted a peak load of $156 \mathrm{kN}$ at a displacement of $56.5 \mathrm{~mm}$ and finally failed by compression of top concrete at the corner of the opening (Figure 5a). There wasa $14 \%$ reduction in peak capacity when compared to the control slab but with an increase in peak load displacement. Provision of flexural opening has changed the failure mode from brittle shear to ductile flexural mode. This is due to the weak link (reduced cross section because of opening) in the constant moment zone which had a lower moment capacity than the shear capacity of the full cross section in the constant shear zone.

Specimen 3(HCS-150-7.5-NO) served as a control slab. The slab had an initial crack in the constant moment zone at a load of $57 \mathrm{kN}$. Many cracks occurred in the constant moment zone before peak load was reached. A peak load of $99 \mathrm{kN}$ was reached after considerable yielding of strands at a displacement of $67 \mathrm{~mm}$. This slab failed by crushing of top concrete just below the load point. The crushing of concrete and crack distribution can be seen in Figure 6b. Specimen HCS-150-7.5-FOtested at a/d ratio of 7.5 with a flexural opening had a similar failure mode to that of control slab. Cracking was first observed at the corner of opening at a load of $36 \mathrm{kN}$. On further loading, unlike the control slab, crack distribution took place only in the opening zone. Peak load of $64 \mathrm{kN}$ was reached before the slab failed due to crushing of top concrete at the corner of opening. Flexural opening led to $25 \%$ reduction in cross section and $34 \%$ reduction in capacity of the slab. Flexural capacity of the slab not only depends on the cross section but also on the prestressing ratio. In the slabs with cut-outs, out of the six strands, two strands were cut leading to a reduction of $33 \%$ 
in prestressing force of the cross section. Reduction in ultimate strength by $34 \%$ is due to higher stress concentration around the corner of opening because of lesser available prestressing force across the reduced cross section. The test results are given in Table 3 .

From Table 3, it can be seen that the effect of opening is more evident depending on the a/d ratio of the tested specimen. Slab with a/d ratio 3.5 , specimen with a flexure opening (HCS-150-3.5-FO) had a decrease of about $13 \%$. Similar trend is observed in specimens with a/d ratio 7.5. An important point to note from the results is that the provision of flexural opening in shear dominated a/d ratio changed the mode of failure from shear to flexure.

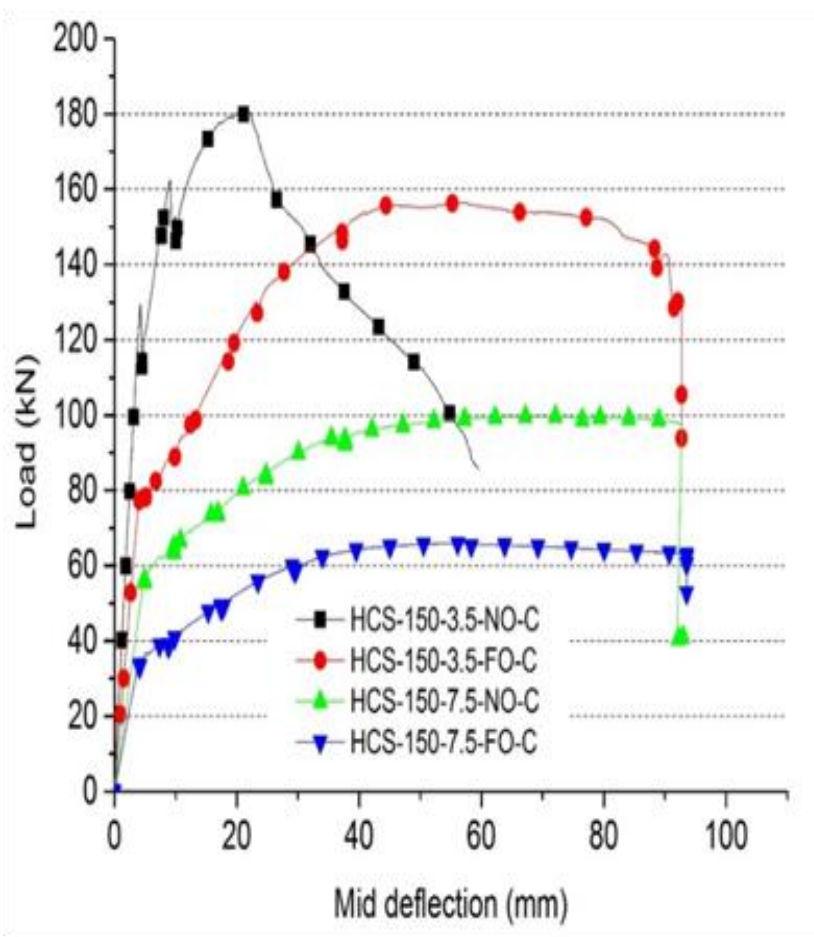

Figure 5: Load vs mid span deflection of slabs

Table 3: Test Results

\begin{tabular}{|l|l|l|l|l|}
\hline & $\begin{array}{l}\text { HCS- } \\
150- \\
3.50-\mathrm{NO}\end{array}$ & $\begin{array}{l}\text { HCS- } \\
150- \\
3.50-\mathrm{FO}\end{array}$ & $\begin{array}{l}\text { HCS- } \\
150- \\
7.50-\mathrm{NO}\end{array}$ & $\begin{array}{l}\text { HCS- } \\
150- \\
7.50-\mathrm{FO}\end{array}$ \\
\hline $\begin{array}{l}\text { Cracking load } \\
\text { (CL) (kN) }\end{array}$ & 129.6 & 80.5 & 57.3 & 35.3 \\
\hline $\begin{array}{l}\text { Percentage (\%) } \\
\text { decrease in CL }\end{array}$ & - & 37.8 & - & 38 \\
\hline $\begin{array}{l}\text { Cracking load } \\
\text { displacement } \\
\text { (mm) }\end{array}$ & 4.3 & 4.3 & 4.4 & 4.1 \\
\hline $\begin{array}{l}\text { Peak load (PL) } \\
\text { (kN) }\end{array}$ & 180.7 & 156.4 & 99.7 & 65.9 \\
\hline $\begin{array}{l}\text { Percentage \% } \\
\text { decrease in PL }\end{array}$ & - & 13.4 & - & 43.5 \\
\hline $\begin{array}{l}\text { Peak load } \\
\text { displacement } \\
\text { (mm) }\end{array}$ & 20.7 & 56.5 & 67.5 & 56.3 \\
\hline Failure Mode & Shear & Flexure & Flexure & Flexure \\
\hline
\end{tabular}

Note: Percentage decrease is calculated based on values of control slab i.e. slab without opening with same $\mathrm{a} / \mathrm{d}$ ratio.

\subsection{Failure Patterns}

Figures $6 \mathrm{a}$ and $6 \mathrm{~b}$ shows the crack patterns and failure modes of the tested slabs. It can be observed that the presence of opening changes the failure modes significantly. The control in series with a/d ratio of 3.5 failed in shear mode.However, the slab with a flexural opening $(\mathrm{a} / \mathrm{d}=3.5)$ failed in a flexure dominant mode with considerable ductility.
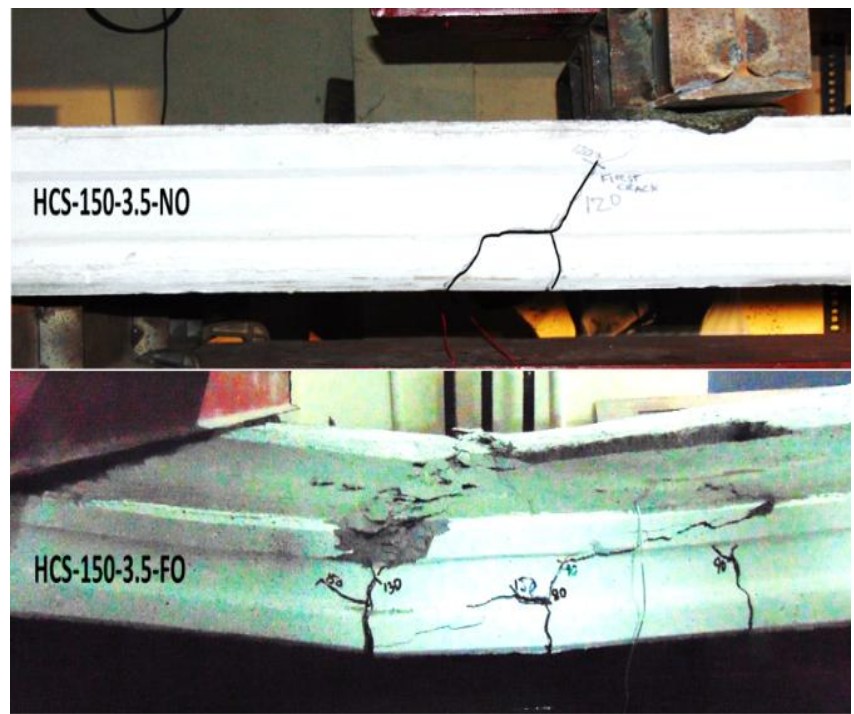

(a) a/d ratio 3.5
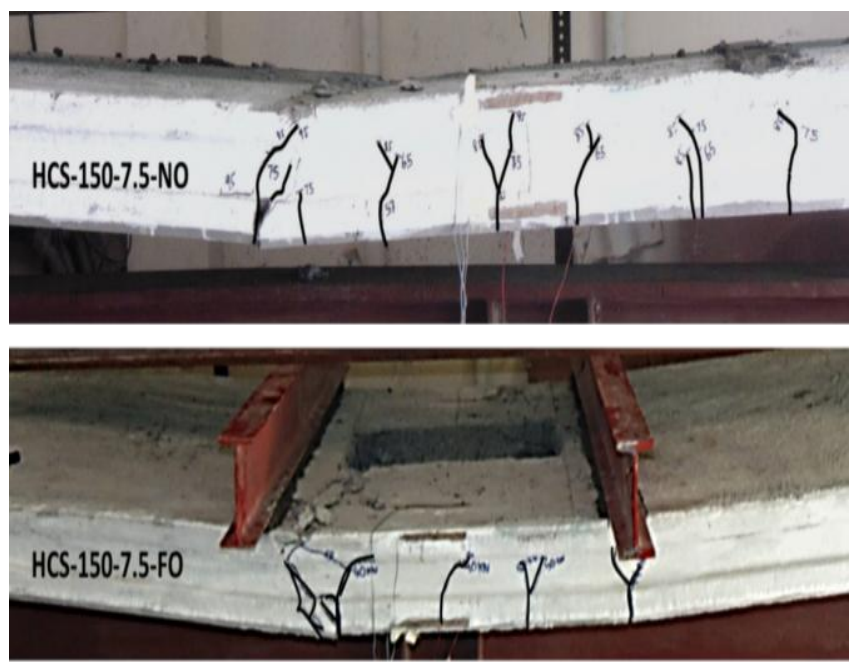

(b) $\mathrm{a} / \mathrm{d}$ ratio 7.5

Figure 6: Crack pattern and Failure modes of slabs

\section{CONCLUSIONS}

Four full scale slabs were tested to evaluate the response of precast prestressedhollowcore slabs with presence of cutouts. Two a/d ratios $(3.5,7.5)$ were chosen as study parameter. Following key conclusions can be derived from the test results presented in this study:

[1]. Presence of opening significantly reduced the ultimate strength of slabs. The reduction in ultimate strength is not proportional to the width of the opening and number of strands cut. For an opening ofwidth equal to $25 \%$ of slab width and with a $33 \%$ reduction in strands 
( 2 out of 6 ), the reduction in capacity reduced upto $44 \%$.

[2]. Opening in the slabs changed the mode of failure. Flexural opening in shear dominated a/d ratio converted the brittle shear failure to a ductile flexural failure.

[3]. Presence of opening causes stress concentration leading to the localization of the cracks around the opening location with no distribution to the surrounding regions.

\section{ACKNOWLEDGEMENTS}

This experimental research was sponsored through Prime Minister (PM) fellowship scheme initiated by confederation of Indian industries (CII) and Department of Science and Technology, India. The authors gratefully acknowledge their generous support. Specimens were cast in casting yard of PRECA Ltd. Their generous support of materials towards this research is also thankfully acknowledged.

\section{REFERENCES}

[1]. Afefy, H. M., and Fawzy, T. M. (2013). "Strengthening of RC one-way slabs including cut-out using different techniques." Engineering Structures, 57, 23-36.

[2]. Al-hafiz, A. M., Chiad, S. S., and Farhan, M. S. (2013). "Flexural Strength of Reinforced Concrete One-Way Opened Slabs with and without Strengthening." Australian Journal of Basic and Applied Sciences, 7(6), 642-651.

[3]. American Concrete Institute (ACI. (2011)). "Building code requirementsfor structural concrete." ACI 3182011, Detroit.

[4]. Anil, Ö., Kaya, N., and Arslan, O. (2013). "Strengthening of one way RC slab with opening using CFRP strips." Construction and Building Materials, 48, 883-893.

[5]. Becker, R. J., and Buettner, D. R. (1985). "Shear Tests of Extruded Hollow-Core Slabs.” PCI Journal, 30(2), 40-54.

[6]. Bentz, E. C. (2000). "Sectional analysis of reinforced concrete members." $\mathrm{PhD}$ thesis,316 pp,University of Toronto.

[7]. Foubert, S. (2014). "Flexural strengthening of prestressed hollow-core slabs using near-surface mounted (NSM) CFRP reinforcement." Phd Thesis, Univesity of Manitoba. 267pp.

[8]. Hawkins, N. M., and Ghosh, S. K. (2006). "Shear strength of Hollow-core slabs." PCI Journal, 51(1), $110-114$.

[9]. Johnson, T., and Ghadiali, Z. (1972). "Load distribution test on precast hollow core slabs with cutouts." PCI Journal, 17(5), 9-19.

[10]. Pajari, M. (1998). "Shear Resistance of PHC Slabs Supported on Beams. II: Analysis." Journal of Structural Engineering, 124(9), 1062-1073.

[11]. Palmer, K. D., and Schultz, A. E. (2011). "Experimental investigation of the web-shear strength of deep hollow-core units." PCI Journal, 56(4), 83-
104.

[12]. Precast/Prestessed concrete Institute (PCI. (1998)). "PCI Manual for the Design ofHollowcore Slabs." PCI MNL 126

[13]. Schreier, H., Orteu, J. J., and Sutton, M. a. (2009). Image correlation for shape, motion and deformation measurements: Basic concepts, theory and applications.,322 pp Springer US, Boston, MA.

[14]. Vecchio, F. J., and Collins, M. P. (1986). "The modified compression-field theory for reinforced concrete elements subjected to shear." ACI Journal Proceedings, 83(2), 219-231.

[15]. Walraven, J, C., and Mercx, W, P, M. (1983). "The bearing capacity for prestressed hollow core slabs." Heron, 28(3), 1-46.

[16]. Yang, L. (1994). "Design of Prestressed Hollow Core Slabs with Reference to Web Shear Failure." Journal of Structural Engineering, 120(9), 2675-2696. 